Portland State University

PDXScholar

\title{
Cell Cycle Arrest Associated with Anoxia-Induced Quiescence, Anoxic Preconditioning, and Embryonic Diapause in Embryos of the Annual Killifish Austrofundulus Limnaeus
}

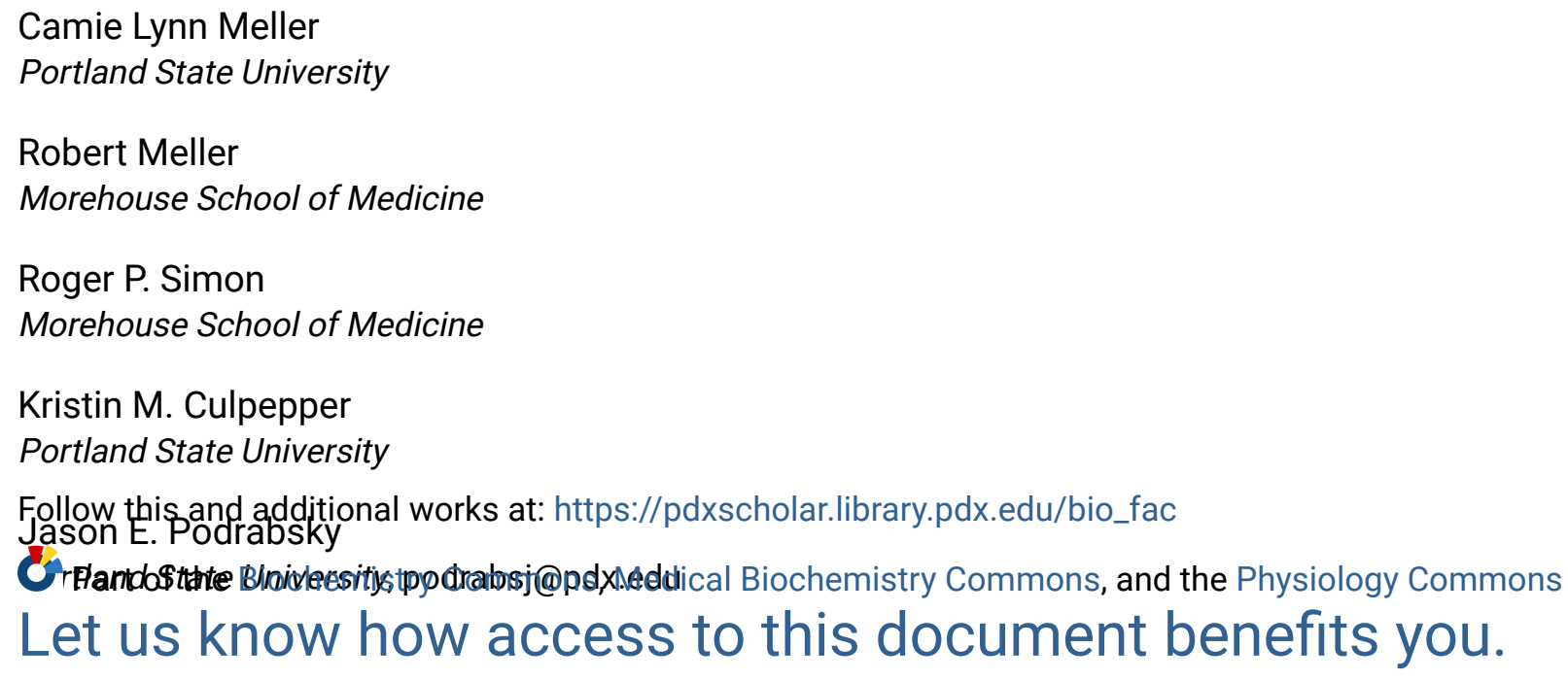

\section{Citation Details}

Meller, Camie Lynn; Meller, Robert; Simon, Roger P.; Culpepper, Kristin M.; and Podrabsky, Jason E., "Cell Cycle Arrest Associated with Anoxia-Induced Quiescence, Anoxic Preconditioning, and Embryonic Diapause in Embryos of the Annual Killifish Austrofundulus Limnaeus" (2012). Biology Faculty Publications and Presentations. 47. https://pdxscholar.library.pdx.edu/bio_fac/47

This Post-Print is brought to you for free and open access. It has been accepted for inclusion in Biology Faculty Publications and Presentations by an authorized administrator of PDXScholar. Please contact us if we can make this document more accessible: pdxscholar@pdx.edu. 


\title{
Cell cycle arrest associated with anoxia-induced quiescence, anoxic preconditioning, and embryonic diapause in embryos of the annual killifish Austrofundulus limnaeus
}

\author{
Camie L. Meller ${ }^{1}$, Robert Meller ${ }^{2}$, Roger P. Simon ${ }^{3}$, Kristin M. Culpepper ${ }^{1}$, and Jason E. \\ Podrabsky ${ }^{1,{ }^{*}}$ \\ ${ }^{1}$ Department of Biology, Portland State University, P.O. Box 751, Portland, OR 97207-0751 \\ ${ }^{2}$ Department of Anatomy and Neurobiology, Morehouse School of Medicine, 720 Westview Dr. \\ SW, Atlanta, GA 30310-1495
}

${ }^{3}$ Department of Internal Medicine, Morehouse School of Medicine, 720 Westview Dr. SW, Atlanta, GA 30310-1495

\begin{abstract}
Embryos of the annual killifish Austrofindulus limnaeus can enter into dormancy associated with diapause and anoxia-induced quiescence. Dormant embryos are composed primarily of cells arrested in the $G_{1} / G_{0}$ phase of the cell cycle based on flow cytometry analysis of DNA content. In fact, most cells in developing embryos contain only a diploid complement of DNA, with very few cells found in the $S, G_{2}$, or M phases of the cell cycle. Diapause II embryos appear to be in a $G_{0}$ like state with low levels of cyclin D1 and p53. However, the active form of pAKT is high during diapause II. Exposure to anoxia causes an increase in cyclin D1 and p53 expression in diapause II embryos, suggesting a possible re-entry into the cell cycle. Post-diapause II embryos exposed to anoxia or anoxic preconditioning have stable levels of cyclin D1 and stable or reduced levels of p53. The amount of pAKT is severely reduced in $12 \mathrm{dpd}$ embryos exposed to anoxia or anoxic preconditioning. This study is the first to evaluate cell cycle control in embryos of $A$. limnaeus during embryonic diapause and in response to anoxia and builds a foundation for future research on the role of cell cycle arrest in supporting vertebrate dormancy.
\end{abstract}

\section{Keywords}

anoxia; p53; AKT; diapause; cyclin D1

\section{Introduction}

The annual killifish, Austrofundulus limnaeus is a cyprinodont fish that is endemic to ephemeral ponds in regions of northern South America where it is most commonly found in the Maracaibo basin of Venezuela (Lilyestrom and Taphorn, 1982; Taphorn and Thomerson, 1978), a region that has been described as having extreme fluctuations in temperature and drought conditions (Podrabsky et al., 1998). The adult and juvenile forms die on a seasonal basis when their ponds desiccate during the dry season (Nico and Thomerson, 1989). This severe and unpredictable climate has given rise to several unique developmental adaptations, including the ability to enter a profound state of metabolic dormancy termed diapause, which allows populations of $A$. limnaeus to persist under conditions that are lethal to almost 
all other species of fish (Myers, 1952; Wourms, 1972a, b). In this paper, we explore regulation of the cell cycle during entrance into metabolic dormancy associated with entrance into diapause and anoxia-induced quiescence in embryos of $A$. limnaeus.

Diapause in annual killifish is a state of developmental and metabolic arrest that occurs as a part of normal development (Podrabsky and Hand, 1999). Entrance into diapause occurs prior to the onset of environmental stress, and thus embryos will enter dormancy under conditions that are conducive to active development (aerobic incubation in aqueous medium). There are three distinct stages of diapause (diapause I, II, and III) that embryos may enter (Wourms, 1972b), with diapause II and III being common in A. limnaeus (Podrabsky and Hand, 1999). Diapause II has been studied in the most detail and is likely the stage of diapause that is most relevant for survival of embryos through the dry season (Podrabsky et al., 2001; Podrabsky et al., 2012). Diapause II embryos arrest about midway through development, after the initiation of neurulation and somitogenesis, but just prior to the onset of organogenesis of the digestive system. Diapause II embryos possess the foundations of the central nervous system including a differentiated fore-, mid-, and hindbrain, optic cups, otic vesicles, olfactory placodes, as well as 38-42 pairs of somites (precursors to trunk musculature and bone), and a functional tubular heart (Podrabsky and Hand, 1999). When incubated at $25^{\circ} \mathrm{C}$ over $80 \%$ of the embryos will enter diapause II, while incubation at higher temperatures causes embryos to develop along an alternate developmental trajectory directly to diapause III (Podrabsky et al., 2010). Diapause II is characterized by a dramatic and severe decrease in metabolic rate (Podrabsky and Hand, 1999), cessation of the ontogenetic increase in DNA typically associated with development (Podrabsky and Hand, 1999), a global arrest of protein synthesis (Podrabsky and Hand, 2000), and extremely low water and ion permeability and ion-motive ATPase activity (Machado and Podrabsky, 2007). Diapause III occurs in a fully developed embryo that is ready to hatch into a feeding larva. While much less is known about the physiology of this stage of diapause, it is accompanied by a severe reduction in metabolic rate (Podrabsky and Hand, 1999). Diapause III is obligate in most embryos independent of incubation temperature.

Early embryos of $A$. limnaeus are extemely resistant to a variety of harsh environmental conditions including a wide range of salt concentrations (Machado and Podrabsky, 2007), complete lack of oxygen (Fergusson-Kolmes and Podrabsky, 2007; Podrabsky et al., 2007; Podrabsky et al., 2012), and complete dehydration of their habitat (Podrabsky et al., 2001). Tolerance of environmental stress typically peaks during diapause II and is retained for several days after embryos resume active development (Machado and Podrabsky, 2007; Podrabsky et al., 2007). Embryos of $A$. limnaeus have a unique and unequalled ability among vertebrates to withstand extended periods of anoxia (maximum lethal time to 50\% mortality of $65 \mathrm{~d}$ at $25^{\circ} \mathrm{C}$ (Podrabsky et al., 2007)). Tolerance to anoxia is gained during early development, peaks during diapause II, and subsequently starts to decline about $8 \mathrm{~d}$ of post-diapause II development (Table 1, Podrabsky et al., 2007). In addition, increased tolerance of anoxia can be induced by "anoxic preconditioning" in some embryonic stages (Podrabsky et al., 2012), allowing for comparisons of mechanisms associated with developmentally-acquired, and environmentally-induced tolerance of anoxia. Thus, anoxiatolerant and anoxia-sensitive individuals can be compared within the same species and in response to different mechanisms of induction, making $A$. limnaeus an excellent model for studying the molecular changes associated with survival of oxygen deprivation in vertebrates.

We determined the phase of cell cycle arrest for $A$. limnaeus embryos during entry into metabolic dormancy associated with diapause and anoxia-induced quiescence. The rationale arose from studies of cells from zebrafish embryos arrested in $S$ and $G_{2} / M$ phase following

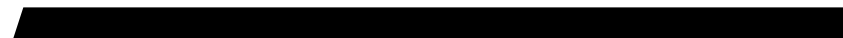


anoxia (Padilla and Roth, 2001). Zebrafish, however, do not exhibit long-term tolerance to anoxia, and thus the significance of this type of cell cycle arrest is unclear. Determining the point in the cell cycle at which cells with exceptional anoxia tolerance arrest during dormancy will aid in determining what intracellular conditions are necessary for supporting metabolic dormancy associated with diapause and anoxia-induced quiescence.

We hypothesized that, as a naturally anoxia-tolerant organism, $A$. limnaeus embryos possess a mechanism for arresting progress through the cell cycle in the $\mathrm{G}_{1}$ phase, prior to replication of their DNA. From this hypothesis predictions can be made based on the levels and activities of proteins known to regulate the $G_{1}$ phase of the vertebrate cell cycle. High levels of cyclin D1 are required for active progression through $\mathrm{G}_{1}$ in early zebrafish embryos (Yarden et al., 1995), and thus we predicted that levels of cyclin D1 would be low in embryos entering metabolic dormancy associated with diapause II and anoxia. Similarly, high levels of the phosphorylated active form of protein kinase B (pAKT, phosphoryated at serine 473) are known to repress the expression and activity of cell cycle inhibitors (Hers et al., 2011), which lead to the prediction that levels of pAKT would be low in dormant embryos. Conversely, we predicted that levels of the protein p53, a stress-inducible negative regulator of cell cycle progression, would be upregulated in diapausing and anoxic embryos.

\section{Materials and Methods}

\section{Husbandry of adults and collection of embryos}

Adult Austrofundulus limnaeus were cared for and embryos were collected as described previously (Podrabsky, 1999) according to protocols approved by the PSU IACUC. Embryos were sampled throughout all the major phases of normal development and including diapauses II and III as described in Table 1. Embryos were staged in days postfertilization (dpf) from fertilization through diapause II. After $32 \mathrm{dpf}$, diapause II was experimentally broken by exposing the embryos to an elevated temperature of $33^{\circ} \mathrm{C}$ and continuous light for $48 \mathrm{~h}$ after which they were returned to the routine incubation conditions of $25^{\circ} \mathrm{C}$ in the dark. Embryos that broke diapause II and resumed development after the $48 \mathrm{~h}$ treatment were used to create a cohort of synchronously developing embryos for postdiapause II development. Post-diapause I embryos were staged in days post-diapause II (dpd).

\section{Exposure to Anoxia}

Embryos were exposed to anoxia as previously described (Podrabsky et al., 2007). Briefly, embryos were washed and transferred to a glass vial with nitrogen-purged embryo medium (45-60 min of robust bubbling). To ensure anoxic conditions, sodium sulfite was added to a final concentration of $1 \mathrm{mg} / \mathrm{ml}$ to scavenge residual oxygen. This amount of sodium sulfite has been previously illustrated to have no toxic effect on the embryos (Podrabsky et al., 2007). The vials were sealed, placed in a plastic bell jar purged with $\mathrm{N}_{2}$ gas for $5 \mathrm{~min}$, and then stored under vacuum at $25 \pm 1^{\circ} \mathrm{C}$.

For anoxic preconditioning, embryos were exposed to anoxia as described above for $48 \mathrm{~h}$. Embryos were then allowed to recover from anoxia for $24 \mathrm{~h}$ under normoxic conditions in a plastic culture dish at $25^{\circ} \mathrm{C}$ prior to exposure to long-term anoxia.

\section{Cell Cycle Analysis by Flow Cytometry}

Cells were isolated for flow cytometry from embryos (Table $1 ; \mathrm{n}=2$ for early development diapause II, $\mathrm{n}=3$ for post-diapause II embryos) exposed to normoxia or $24 \mathrm{~h}$ of anoxia. To prepare cells, 200 to 300 embryos were dissociated into single-cell suspensions by pressing them through a $500 \mu \mathrm{m}$-mesh basket (Netwell, Corning Product \#3480) with a glass pestle 
into a $50 \mathrm{~mm}$ Petri dish. Cell suspensions were then rinsed several times in serum-free L-15 (CellgroR Leibovitz's L-15 Medium with L-glutamine \#10-045-CV) media to remove yolk proteins, pelleted by centrifugation ( $300 \times \mathrm{g}, 5 \mathrm{~min}$ ) and resuspended in $200 \mu \mathrm{l}$ of phosphate buffered saline (PBS). Cells were then permeabilized and fixed by the addition of $1 \mathrm{ml}$ methanol (100\%) and then incubated in a solution of $1 \mathrm{mg} / \mathrm{ml}$ propidium iodide (PI) for 10 min at room temperature. Cells were then washed with PBS and stored at $4{ }^{\circ} \mathrm{C}$ until analysis via flow cytometry. Just prior to flow cytometry analysis, the cells were washed through a $30 \mu \mathrm{m}$ mesh to maximize cell dissociation. Cells were analyzed by flow cytometry (Cytopeia Influx Analyzer, Cytopeia Incorporated @2004) at the Oregon Stem Cell Center, Flow Cytometry Core at Oregon Health \& Science University. Several thousand cells were analyzed for each sample.

\section{Western Blots}

Protein levels of cyclin D1, p53 and, phosphorylated AKT (pAKT-serine 473) were quantified using western blot analysis. For levels of cyclin D1 and p53, cells were harvested from whole embryos at the following developmental stages: diapause II, $4 \mathrm{dpd}$, and $12 \mathrm{dpd}$. Embryos were sampled under control normoxic conditions ( $\mathrm{t}=0$ ), after exposure to long-term anoxia (for each stage, a time that is $50 \%$ of the $\mathrm{LT}_{50}$ for anoxia at $25^{\circ} \mathrm{C}$ : DII $=21 \mathrm{~d}, 4 \mathrm{dpd}$ $=32 \mathrm{~d}, 12 \mathrm{dpd}=72$ hours), and after $24 \mathrm{~h}$ of subsequent normoxic recovery from anoxia. Embryos at 12 dpd were treated with an additional "anoxic preconditioning" regime as presented in Figure 1. For pAKT, only 12 dpd embryos were sampled under control conditions and in response to anoxia and recovery from anoxia. Three independent protein lysates were prepared for cyclin D1 and p53 all treatments, while four were prepared for pAKT.

Fish embryos contain a large amount of yolk proteins in the yolk compartment that are physically separated from the embryonic cells. These yolk proteins must be removed in order to clearly examine the proteins that are expressed in embryonic tissues. Thus, we separated the embryonic cells from the aqueous-miscible yolk prior to extraction of proteins for immunoblot analysis. Embryos (50-100) were transferred to a $500 \mu \mathrm{m}$-mesh basket (Netwell , Corning Product \#3480) in a $50 \mathrm{~mm}$ Petri dish containing $2 \mathrm{ml}$ of PBS with protease inhibitor (Roche Complete Mini, \#11836153001). Embryos were dissociated into cell suspensions by forcing the embryos through the mesh using a flat-bottom glass pestle. The embryonic cells were then separated from the yolk by centrifugation in a $1.7 \mathrm{ml}$ microcentrifuge tube at $300 \times g$ for $5 \mathrm{~min}$ at $4^{\circ} \mathrm{C}$. The cell pellet was then rinsed two times in ice-cold PBS with protease inhibitor to remove yolk proteins. After the final rinse, the cells were pelleted (as above) and frozen in liquid nitrogen. Samples were stored at $-80^{\circ} \mathrm{C}$ until the day of analysis. While the total protein content of the embryo is known to decrease during development (Podrabsky and Hand, 1999; Machado and Podrabsky, 2007), this process separates the cells from the large yolk mass, and thus eliminates this possibly confounding variable.

Embryo lysates were prepared for immunoblot by lysing the cells in a buffer $(0.1 \mathrm{M} \mathrm{NaCl}$, $0.02 \mathrm{M}$ Tris-HCl, $\mathrm{pH} 7.6,1 \mathrm{mM}$ EDTA, $\mathrm{pH}$ 8.0, 1\% NP-40) containing protease inhibitors (0.99 $\mu \mathrm{g} / \mathrm{ml}$ aprotinin, $0.3 \mu \mathrm{g} / \mathrm{ml}$ leupeptin, $1.5 \mu \mathrm{g} / \mathrm{ml}$ pepstatin and $15 \mu \mathrm{g} / \mathrm{ml}$ PMSF). Additionally, a phosphatase inhibitor cocktail (10\% v/v, Sigma P2850) was included and used as prescribed by the manufacturer. Lysates were sonicated at $15 \%$ amplitude for 10 to $15 \mathrm{sec}$ (Branson Digital Sonifier, S-450D). Total protein was determined using Bradford (Bio-Rad) or micro BCA (Pierce) protein assays.

Equal amounts of total protein were loaded for each sample. For cyclin D1 and p53, $25 \mu \mathrm{g}$ protein were loaded in each well. For developmental profiling of pAKT, $125 \mu \mathrm{g}$ of total protein were loaded for each well, while $100 \mu \mathrm{g}$ of protein were loaded per well for the blots 
evaluating pAKT levels during exposure to anoxia. Proteins were then separated on a $10 \%$ SDS-polyacrylamide gel (110-150 V for $\sim 2 \mathrm{~h}$ ), followed by transfer onto PVDF membranes ( $30 \mathrm{~V}$, overnight). Membranes were blocked for $30 \mathrm{~min}$ at room temperature (RT) with 5\% nonfat dried milk in Tris-buffered saline with $0.1 \%$ Tween-20 (TBST) for cyclin D1 and p53 or $5 \% \mathrm{BSA} / \mathrm{TBST}$ for pAKT, followed by incubation with primary antibody in the same respective buffer for $2 \mathrm{~h}$ at RT (cyclin D1, Neomarkers Rb-010-PO diluted 1:1000; p53, Santa Cruz 6243 diluted 1:500) or overnight at $4^{\circ} \mathrm{C}$ for pAKT (Cell Signaling 4060, to phospho-serine 473 diluted 1:2000). Membranes were then washed four times (10 min each) in TBST at RT prior to incubation in secondary antibody (HRP-conjugated anti-rabbit, Cell Signaling 7074 diluted 1:2000 for cyclin D1 and p53; Abcam ab97051 diluted 1:8000 for pAKT) for $1 \mathrm{~h}$ at RT in the same buffer as listed above for the primary antibody. Prior to detection, membranes were washed again as described above. Antigen binding was determined by chemiluminescence (Visualizer Western Blot Detection Kit, Millipore 64-201), detected using a digital image station (Kodak 2000RT) and analyzed with 1D 3.6 or NIH Image $\mathbf{J}$ software. Band intensity expressed as OD units was used to quantify protein levels. All samples were normalized to the band intensity of a pooled embryonic sample representing embryos of various stages under normoxic conditions. This approach was necessary in order to create a large single sample that could be loaded onto multiple gels for the purpose of allowing all developmental stages and blots to be compared on a common scale. Relative amounts of protein were expressed as a fraction of the normoxic control levels for 4 dpd embryos.

\section{Statistical Analyses}

Mean time to 50\% mortality in anoxia was estimated using Probit regression analysis (SPSS v19, IBM Company). This analysis provides a mean and 95\% confidence interval (CI) for time to reach 50\% survival, and compares the $95 \% \mathrm{CI}$ of control and experimental conditions using a relative mean potency analysis. In addition, these survival data were analyzed by two-way analysis of variance (ANOVA, Prism v5, GraphPad Software Inc.). For cell cycle analysis, the proportions of cells (transformed using the $\arcsin \downarrow p$ transform (Zar, 1996)) in the $\mathrm{G}_{1}$ stage of the cell cycle were compared using two-way ANOVA with post-hoc comparisons of means using Bonferroni's correction for multiple comparisons (Prism v5). Relative protein concentrations were compared using ANOVA on transformed data (arcsin $\downarrow p$ or $\ln$, whichever provided a normal distribution of the data) and Tukey's test for post-hoc comparisons when comparing different developmental stages and Dunnett's post-hoc test when evaluating the effect of anoxia (Prism v5).

\section{Results}

\section{Cell Cycle Arrest}

Most of the cells isolated from early embryos of $A$. limnaeus contain only a diploid amount of DNA, and thus we conclude that nearly all of cells are in the $\mathrm{G}_{1} / \mathrm{G}_{0}$ phase of the cell cycle for most of early development (Fig 2A). Exposure to anoxia does not significantly alter the distribution of cells (two-way ANOVA, $p>0.05$ ); thus, cells arrest in their current phase of the cell cycle (Fig 2B). However, 3 dpf embryos have a number of S-phase cells under normoxia that are not present after $24 \mathrm{~h}$ of anoxia (Fig 2A). As anoxia does not have an effect on the proportion of cells that are in the $\mathrm{G}_{1} / \mathrm{G}_{0}$ phase of the cell cycle, the control and anoxia treatments were combined and then tested for developmental differences in the distribution of cells in $\mathrm{G}_{1}$. There is a significant increase in the proportion of cells that are in $\mathrm{G}_{1}$ associated with progression through early development from $61.5 \pm 2.5 \%$ (mean $\pm \mathrm{sd}$ ) in embryos at $3 \mathrm{dpf}$ to $92.7 \pm 2.3 \%$ at $14 \mathrm{dpf}$ (Fig $2 \mathrm{~B}$, two-way ANOVA, $<<0.001$ ). 
Post-diapause II development is also characterized by a high proportion of cells in the $\mathrm{G}_{1}$ phase of the cell cycle (Fig 3A). However, there is a significant shift in the proportion of cells in $\mathrm{G}_{1}$ during the course of development from a low of $76 \pm 0.5 \%$ (mean \pm sd) in $4 \mathrm{dpd}$ embryos to a high of $91 \pm 1.3 \%$ in 36 dpd embryos that had entered diapause III (two-way ANOVA, $\mathrm{p}<0.001)$. Exposure to anoxia does not significantly alter the distribution of cells that are in $\mathrm{G}_{1}$ in post-diapause II embryos (Fig 3B; two-way ANOVA, p>0.05).

\section{Anoxic Preconditioning}

Total survival time was not enhanced by the anoxic preconditioning as used here, with both sets of embryos reaching $0 \%$ survival by $18 \mathrm{~d}$ of anoxia (Fig 4). However, the initial survival of the embryos was significantly enhanced as evidenced by an increase in the $\mathrm{LT}_{50}$ value from $7.4 \pm 0.7 \mathrm{~d}$ (mean $\pm 95 \%$ C.I.) in control embryos to $10.2 \pm 0.7 \mathrm{~d}$ in embryos preconditioned to anoxia (two-way ANOVA, $F(7,56)=122.57, p<0.0001$; Probit regression relative mean potency analysis, $\mathrm{p}<0.05)$.

\section{p53}

\section{Cyclin D1}

The levels of p53 are very low in normoxic diapause II embryos, and are significantly lower than either stage of post-diapause II development (Fig 5; ANOVA, $F(2,6)=8.35$, Tukey's $\mathrm{p}=0.019$ ). Upon exposure to anoxia, however, levels of p53 protein increased significantly compared to controls (ANOVA, $F(2,6)=6.69, p=0.0296$, Dunnett's, $p<0.05$ ). After 24 hours of normoxic recovery the levels of p53 decreased by $\sim 50 \%$ but remained significantly higher than the normoxic control. Embryos at 4 and 12 dpd constitutively express p53 protein under aerobic conditions. However, in response to anoxia p53 decreased by $~ 50 \%$ compared to control values although the decrease was not statistically significant in either sample set (ANOVA, $4 \mathrm{dpd}, F(2,6)=4.90, p=0.055 ; 12 \mathrm{dpd}, F(2,6)=1.03, p=0.41)$. Aerobic recovery for $24 \mathrm{~h}$ returned p53 to control levels in both stages of post-diapause II development. Anoxic preconditioning (Fig 1), had no significant effect on the expression of p53 protein in $12 \mathrm{dpd}$ embryos (Fig 5; ANOVA, $F(6,14)=1.75, p=0.18$ ).

Cyclin D1 is expressed at low levels in aerobic diapause II embryos compared to embryos at $4 \mathrm{dpd}$, but not those at $12 \mathrm{dpd}$ (Fig 6; ANOVA, $F(2,6)=5.2, p=0.049$ ). Exposure to $48 \mathrm{~h}$ of anoxia resulted in a significant increase in cyclin D1 in diapause II embryos that remained after $24 \mathrm{~h}$ of aerobic recovery (ANOVA, $F(2,6)=6.49, p=0.032$, Dunnett's $p<0.05$ ). Embryos at 4 dpd have higher levels of cyclin D1 compared to both diapause II embryos and those 12 dpd (ANOVA, $F(2,6)=5.2$, Tukey's $\mathrm{p}=0.049$ ). Anoxia does not alter the levels of cyclin D1 in either stage of post-diapause II embryos (ANOVA, $4 \mathrm{dpd}, F(2,6)=0.005, p=0.99 ; 12 \mathrm{dpd}$, $F(6,14)=0.64, p=0.69)$.

\section{PAKT}

Levels of phosphorylated (presumably active) AKT (pAKT) are relatively high during all of early development (4dpf $-4 \mathrm{dpd}$ ) compared to embryos in late post-diapause II development $(16-32 \mathrm{dpd}$; ANOVA, $F(11,27)=9.6$, p $<0.0001$; Fig 7$)$. However, the pattern is complex, with a large peak in relative abundance occurring at $12 \mathrm{dpd}$ compared to all other developmental stages. Aside from this significant, but unexplained peak in relative abundance, the general trend is for high levels of pAKT in early development through $4 \mathrm{dpd}$ and low levels in late development. We have observed this pattern of pAKT abundance on at least 8 different protein lysates, representing several independent spawning events and cell isolations and repeatedly got a spike in expression at $12 \mathrm{dpd}$. 
Exposure to $48 \mathrm{~h}$ of anoxia causes a rapid and severe decrease in the amount of pAKT in embryos at $12 \mathrm{dpd}$ and these levels remain significantly depressed even after $24 \mathrm{~h}$ of aerobic recovery (Fig 8; ANOVA, $F(5,17)=146.8, \mathrm{p}<0.0001$, Dunnett's p<0.0001).

\section{Discussion}

\section{Cell Cycle Arrest During Diapause II}

Most cells isolated from A. limnaeus embryos were found in the $\mathrm{G}_{1} / \mathrm{G}_{0}$ phase of the cell cycle, an unlikley result considering the relatively rapid proliferation associated with active development. This contrasts to a number of studies on cell cycle progression in fish embryos, where a significant number of cells are found in the $\mathrm{S}$ or $\mathrm{G}_{2}$ phases of the cell cycle (Padilla and Roth, 2001; Schlueter et al., 2007). It is not known if this pattern of cell behavior is due to a prolonged $\mathrm{G}_{1}$ phase or minimization of the time spent in $\mathrm{S} / \mathrm{G}_{2} / \mathrm{M}$ phases of the cell cycle. The relatively slow rates of development in A. limnaeus (35-40 d for escape embryos at $25^{\circ} \mathrm{C}$, (Chennault and Podrabsky, 2010)) compared to other species of fish such as Fundulus heteroclitus with similar sized eggs (12-14 d at $20^{\circ} \mathrm{C}$, (DiMichele and Taylor, 1980)) circumstantially supports a prolonged $\mathrm{G}_{1}$ phase. Further, the relatively low expression levels of cyclin D1 reported in this paper (see below) would suggest a prolonged $\mathrm{G}_{1}$ phase as well. In insects, data on three species indicate one arresting in $\mathrm{G}_{1} / \mathrm{G}_{0}$ and two arresting in $\mathrm{G}_{2} / \mathrm{M}$ during diapause (Denlinger, 2002). In delayed-implanting mouse blastocysts, the majority of cells are arrested in $G_{1} / G_{0}$ (Sherman and Barlow, 1972). Arresting in $\mathrm{G}_{1} / \mathrm{G}_{0}$ during diapause may favor long-term survival for several reasons. First, the integrity of only a single copy of the genome must be maintained, reducing the chances of damage and the cost of genome maintenance. In addition, relatively fragile structures associated with mitosis, such as the mitotic spindle would not have to be protected and stabilized in the face of an unpredictable and likely extreme environment. The fragility of the mitotic/meitotic spindle is somewhat debatable considering the data above on $\mathrm{G}_{2} / \mathrm{M}$ phase arrest in insect diapause and the fact that mammalian oocytes survive for decades arrested in the middle of meiosis. However, oocytes are protected from environmental stress compared to free-living vertebrate embryos, and perhaps the relatively controlled environment of the mammalian reproductive system facilitates prolonged arrest during $\mathrm{M}$ phase.

\section{Regulation of $\mathrm{G}_{\mathbf{1}} / \mathrm{G}_{\mathbf{0}}$ Arrest in Diapause II}

In this study two $G_{1}$ signaling pathways were investigated, p53 and pAKT, both of which can regulate the activity of cyclin-dependent kinase (CDK) inhibitors (Choi and Donehower, 1999; Hers et al., 2011; Lesser et al., 2001; Mocanu and Yellon, 2003). Cell cycle arrest in diapause II appears to be p53-independent based on the low expression levels observed in normoxic embryos. The expression pattern of pAKT during diapause II is surprisingly opposite to what would be expected for a population of cells arrested in $\mathrm{G}_{1}$. Active pAKT is known to negatively regulate CDK inhibitors, and thus would be more consistent with progression through $\mathrm{G}_{1}$. In addition to its role in cell cycle progression, pAKT is also known to block apoptotic programmed cell death (Hers et al., 2011). Thus, without additional data on levels or activity of CDK inhibitors (e.g. p21, p27), high pAKT must be interpreted as a pro-survival signal in diapause II embryos.

The D-type cyclins are a $G_{1}$-specific group of cyclins necessary for progression through $G_{1}$ to $S$-phase, and out of $\mathrm{G}_{0}$ into $\mathrm{G}_{1}$ (Burch and Heintz, 2005). In zebrafish development, cyclin $\mathrm{D} 1$ is the critical $\mathrm{G}_{1}$ phase cyclin expressed during early development through somitogenesis (Yarden et al., 1995). Low cyclin D1 during diapause II could be interpreted as a mechanism to slow progression through $G_{1}$ and perhaps arrest in $G_{1}$ or more likely $G_{0}$ (Burch and Heintz, 2005). Our understanding of cell cycle control during embryogenesis is 
still far from complete (Burch and Heintz, 2005) and further exploration of cell cycle regulation in A. limnaeus embryos is likely to contribute to a better understanding of cell cycle control during vertebrate development as well as in response to metabolic dormancy.

\section{Cell Cycle Arrest in Anoxia-induced Quiescence}

When exposed to anoxia, A limnaeus embryonic cells arrest in whatever phase of the cell cycle they are in, which results in mostly $\mathrm{G}_{1}$ arrest due to the particular pattern of cell cycle progression in this species (see above). Early embryos at $3 \mathrm{dpf}$ are the one exception to this generalization, as they exhibit a number of cells in $\mathrm{S}$ phase under aerobic conditions, but not under anoxic conditions. These cells presumably either die immediately or progress to $\mathrm{G}_{2}$ or on to $\mathrm{G}_{1}$ within the first $24 \mathrm{~h}$ of anoxia, however the majority of the cells still arrest in $\mathrm{G}_{1}$. This pattern of predominantly $\mathrm{G}_{1}$ arrest contrasts the available data for anoxia-induced arrest in zebrafish embryos, which arrest in $\mathrm{S}(77.7 \%)$ and the $\mathrm{G}_{2} / \mathrm{M}(22.3 \%)$ phases (Padilla and Roth, 2001). It is worth noting that zebrafish embryos survive for only $24 \mathrm{~h}$ of anoxia, a survival time that is typical of all vertebrate embryos (Podrabsky et al., 2012). Therefore this pattern of cell cycle arrest may not be adaptive or reflect a mechanism for long-term survival of anoxia. It is currently not clear if $\mathrm{G}_{1}$ arrest in response to anoxia is protective or adaptive in embryos of A. limnaeus. Experimental induction of $\mathrm{S}_{\text {or }} \mathrm{G}_{2}$ arrest prior to exposure to anoxia may shed light on this issue.

\section{Regulation of Cell Cycle Arrest in Anoxia}

From a molecular perspective, it appears that diapause II embryos respond to anoxia in a manner that is distinct from post-diapause II embryos. While p53 levels are not affected by anoxia in post-diapause II embryos, they signficiantly increase in diapause II embryos. Since the cells are already arrested in diapause II, increased p53 may be playing a role as a prosurvival signal to help prevent apoptosis or to regulate metabolic pathways (Almog and Rotter, 1997; Choi and Donehower, 1999; Vousden and Ryan, 2009). The p53 protein is known to play a critical role in normal embryonic development (Almog and Rotter, 1997; Choi and Donehower, 1999), and thus it is not surprising that basal levels are elevated in 4 and 12 dpd embryos. Stable or decreased levels of p53 in these post-diapause II stage embryos may indicate a lack of a role for this protein in cell cycle arrest during anoxia. However, we have no information on post-translational modifications or actual p53 activity in these embryos, and thus additional studies would be needed to fully evaluate the meaning of these data.

Cyclin D1 levels increase in diapause II embryos exposed to anoxia, although the levels remain below those observed in 4 dpd embryos. An increase of cyclin D1 in anoxic diapause II embryos is consistent with reentry into the cell cycle in $\mathrm{G}_{1}$, and may seem counterintuitive. Mammalian neurons have been reported to re-enter the cell cycle upon exposure to ischemia, a decision ultimately fatal for the cells (Katchanov et al., 2001). Perhaps diapause II embryos (which are composed primarily of nervous system tissue) share this conserved pathway with respect to their response to anoxia, but have evolved mechanisms to prevent cell death through suppression of apoptotic pathways. In contrast, 4 and $12 \mathrm{dpd}$ embryos experience no change in cyclin D1 protein levels in response to anoxia. This is consistent with previous studies on mammalian cells (Jirmanova et al., 2002).

Anoxia causes a rapid and severe decrease in levels of pAKT in 12 dpd embryos. This result is consistent with reports for decreased pAKT in the brain of the anoxia-tolerant Crucian carp (Stenslokken et al., 2008), but is opposite to that reported for brain of anoxia-tolerant turtles (Milton et al., 2008). Thus, no clear pattern for expression of pAKT is apparent based on the three anoxia-tolerant species investigated. The severe reduction in pAKT observed in anoxic embryos of $A$. limnaeus is consistent with cell cycle arrest through the loss of 
negative regulation on CDK inhibitors (Hers et al., 2011). However, loss of pAKT is counter-intuitive from the standpoint of blocking apoptosis (Hers et al., 2011). The fact that pAKT also plays a role in normal development further complicates the interpretation of these data. Unfortunately, the response of pAKT to anoxia in diapause II and 4 dpd embryos is currently not known.

\section{Cell Cycle Regulation in Anoxic Preconditioning}

Anoxic preconditioning in 12 dpd embryos does not appear to cause major changes in levels of cyclin D1 or p53 proteins. Cyclin D1 is induced in a number of mammalian models for ischemic preconditioning (Burch and Heintz, 2005; Katchanov et al., 2001; Teoh et al., 2002). However, this has been considered a sign that cells have been stimulated to re-enter the cell cycle, and thus may be a maladaptive response that is thwarted in embryos of $A$. limnaeus. The role of p53 in ischemic/anoxic preconditioning is much less clear. It is induced in rat forebrain cells (Tomasevic et al., 1999), but downregulated in rat heart tissue (Mocanu and Yellon, 2003). Thus the insignificant decrease that is observed in preconditioned $A$. limnaeus embryos is difficult to interpret, but there is clearly a trend for decreased expression when the embryos are exposed to anoxia. Further investigation of p53 activity and the levels of its downstream targets are needed to better evaluate its role in preconditioning in embryos of A. limnaeus. One potentially significant result is the reduced levels of pAKT in anoxia preconditioned embryos ( $48 \mathrm{~h}$ anoxia $+24 \mathrm{~h}$ recovery), suggesting that alteration of pAKT signaling may affect anoxic survival. Future studies should focus on the expression of upstream regulators and downstream targets of pAKT in order to evaluate the possible role of this kinase in survival of anoxia.

\section{Conclusion}

Anoxia tolerance is rare among the vertebrates, despite the prevalence of hypoxic and anoxic conditions in aquatic and terrestrial habitats. The extreme tolerance of anoxia exhibited by embryos of $A$. limnaeus represents a departure from other vertebrates and is likely the result of adaptations that cannot be studied in other organisms. This study suggests a number of unique characters in cell cycle regulation associated with metabolic and developmental dormancy. Thus, embryos of $A$. limnaeus provide a useful model for studies focused on identifying new ways to control cell proliferation and promote tolerance of oxygen deprivation in human tissues.

\section{Acknowledgments}

This work was supported by a National Institutes of Health, National Heart, Lung, and Blood Institute grant R01 HL095454 to JEP.

\section{Literature Cited}

Almog N, Rotter V. Involvement of p53 in cell differentiation and development. Biochim Biophys Acta. 1997; 1333:F1-F27. [PubMed: 9294016]

Burch PM, Heintz MH. Redox regulation of cell-cycle re-entry: cyclin D1 as a primary target for the mitogenic effects of reactive oxygen and nitrogen species. Antioxid Redox Sig. 2005; 7:741-751.

Chennault T, Podrabsky JE. Aerobic and anaerobic capacities differ in embryos of the annual killifish Austrofundulus limnaeus that develop on alternate developmental trajectories. J Exp Zool A. 2010; 313A:587-596.

Choi J, Donehower LA. p53 in embryonic development: maintaining a fine balance. Cell Mol Life Sci. 1999; 55:38-47. [PubMed: 10065150]

Denlinger DL. Regulation of Diapause. Annu Rev Entomol. 2002; 47:93-122. [PubMed: 11729070]

DiMichele L, Taylor MH. The environmental control of hatching in Fundulus heteroclitus. J Exp Zool. 1980; 214:181-187. 
Fergusson-Kolmes L, Podrabsky JE. Differential effects of anoxia on heart rate in developmental stages of the annual killifish Austrofundulus limnaeus that differ in their tolerance of anoxia. J Exp Zool A. 2007; 307A:419-423.

Hers I, Vincent EE, Tavare JM. Akt signalling in health and disease. Cell Signal. 2011; 23:1515-1527. [PubMed: 21620960]

Jirmanova L, Afanassieff M, Gobert-Gosse S, Markossian S, Savatier P. Differential contributions of ERK and PI3-kinase to the regulation of cyclin D1 expression and to the control of the G1/S transition in mouse embryonic stem cells. Oncogene. 2002; 21:5515-5528. [PubMed: 12165850]

Katchanov J, Harms C, Gertz K, Hauck L, Waeber C, Hirt L, Priller J, von Harsdorf R, Bruck W, Hortnagl H, Dirnagl U, Bhide PG, Endres M. Mild Cerebral Ischemia Induces Loss of CyclinDependent Kinase Inhibitors and Activation of Cell Cycle Machinery before Delayed Neuronal Cell Death. J Neurosci. 2001; 21:5045-5053. [PubMed: 11438580]

Lesser MP, Farrell JH, Walker CW. Oxidative stress, DNA damage and p53 expression in the larvae of atlantic cod (Gadus morhua) exposed to ultraviolet (290-400 nm) radiation. J Exp Biol. 2001; 204:157-164. [PubMed: 11104719]

Lilyestrom C, Taphorn D. El control biologico de mosquitos mediante peces en la cuenca del Lago de Maracaibo, Venezuela. Informe Tecnico del Vice - Rectorado de Produccion Agricola. 1982; 2:129.

Machado BE, Podrabsky JE. Salinity tolerance in diapausing embryos of the annual killifish Austrofundulus limnaeus is supported by exceptionally low water and ion permeability. J Comp Physiol B. 2007; 177:809-820. [PubMed: 17581754]

Milton SL, Dirk JL, Kara FL, Prentice HM. Adenosine modulates ERK1/2, PI3K/Akt, and p38MAPK activation in the brain of the anoxia-tolerant turtle Trachemys scripta. J Cereb Blood Flow Metab. 2008; 28:1469-1477. [PubMed: 18506199]

Mocanu MM, Yellon DM. p53 down-regulation: a new molecular mechanism involved in ischaemic preconditioning. FEBS Letters. 2003; 555:302-306. [PubMed: 14644432]

Myers GS. Annual fishes. Aquarium J. 1952; 23:125-141.

Nico LG, Thomerson JE. Ecology, food habits and spatial interactions of Orinoco Basin annual killifish. Acta Biol Venez. 1989; 12:106-120.

Padilla PA, Roth MB. Oxygen deprivation causes suspended animation in the zebrafish embryo. Proc Natl Acad Sci USA. 2001; 98:7331-7335. [PubMed: 11404478]

Podrabsky JE. Husbandry of the annual killifish Austrofundulus limnaeus with special emphasis on the collection and rearing of embryos. Env Biol Fish. 1999; 54:421-431.

Podrabsky JE, Carpenter JF, Hand SC. Survival of water stress in annual fish embryos: dehydration avoidance and egg envelope amyloid fibers. Am J Physiol Regul Integr Comp Physiol. 2001; 280:R123-R131. [PubMed: 11124142]

Podrabsky JE, Garrett IDF, Kohl ZF. Alternative developmental pathways associated with diapause regulated by temperature and maternal influences in embryos of the annual killifish Austrofundulus limnaeus. J Exp Biol. 2010; 213:3280-3288. [PubMed: 20833920]

Podrabsky JE, Hand SC. The bioenergetics of embryonic diapause in an annual killifish, Austrofundulus limnaeus. J Exp Biol. 1999; 202:2567-2580. [PubMed: 10482717]

Podrabsky JE, Hand SC. Depression of protein synthesis during diapause in embryos of the annual killifish Austrofundulus limnaeus. Physiol Biochem Zool. 2000; 73:799-808. [PubMed: 11121353]

Podrabsky JE, Hrbek T, Hand SC. Physical and chemical characteristics of ephemeral pond habitats in the Maracaibo basin and Llanos region of Venezuela. Hydrobiologia. 1998; 362:67-78.

Podrabsky JE, Lopez JP, Fan TWM, Higashi R, Somero GN. Extreme anoxia tolerance in embryos of the annual killifish Austrofundulus limnaeus: Insights from a metabolomics analysis. J Exp Biol. 2007; 210:2253-2266. [PubMed: 17575031]

Podrabsky, JE.; Riggs, CL.; Duerr, JM. Anoxia Tolerance During Vertebrate Development - Insights from Studies on the Annual Killifish Austrofundulus limnaeus. In: Padilla, P., editor. Anoxia InTech. 2012. p. 3-24. 
Schlueter PJ, Peng G, Westerfield M, Duan C. Insulin-like growth factor signaling regulates zebrafish embryonic growth and development by promoting cell survival and cell cycle progression. Cell Death Diff. 2007; 14:1095-1105.

Sherman MI, Barlow PW. Deoxyribonucleic acid content in delayed mouse blastocysts. J Reprod Fert. 1972; 29:123-126.

Stenslokken KO, Ellefsen S, Stecyk JAW, Dahl MB, Nllsson GE, Vaage J. Differential regulation of AMP-activated kinase and AKT kinase in response to oxygen availability in crucian carp (Carassius carassius). Am J Physiol Regul Integr Comp Physiol. 2008; 295:R1803-R1814. [PubMed: 18922957]

Taphorn DC, Thomerson JE. A revision of the South American cyprinodont fishes of the genera Rachovia and Austrofundulus, with the description of a new genus. Acta Biol Venez. 1978; 9:377452.

Teoh N, Pena AD, Farrell G. Hepatic ischemic preconditioning in mice is associated with activation of NF- $\kappa B$, p38 kinase, and cell cycle entry. Hepatology. 2002; 36:94-102. [PubMed: 12085353]

Tomasevic G, Shamloo M, Israeli D, Wieloch T. Activation of p53 and its target genes p21WAF1/ Cip1 and PAG608/Wig-1 in ischemic preconditioning. Mo Brain Res. 1999; 70:304-313.

Vousden KH, Ryan KM. p53 and metabolism. Nat Rev Cancer. 2009; 9:691-700. [PubMed: 19759539]

Wourms JP. Developmental biology of annual fishes I. Stages in the normal development of Austrofundulus myersi Dahl. J Exp Zool. 1972a; 182:143-168. [PubMed: 5079083]

Wourms JP. The developmental biology of annual fishes III. Pre-embryonic and embryonic diapause of variable duration in the eggs of annual fishes. J Exp Zool. 1972b; 182:389-414. [PubMed: 4674089]

Yarden A, Salomon D, Geiger B. Zebrafish cyclin D1 is differentially expressed during early embryogenesis. Biochim Biophys Acta Gene Struc Exp. 1995; 1264:257-260.

Zar, JH. Biostatistical Analysis. 3. Prentice Hall; New York: 1996. 
A. Exposure regime for diapause II and 4 dpd embryos

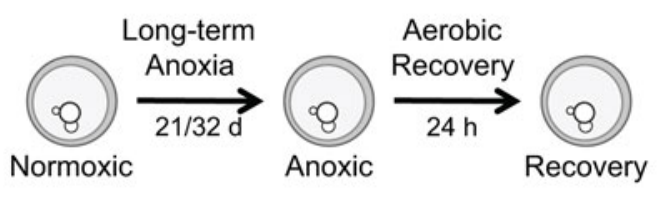

B. Exposure regime for $12 \mathrm{dpd}$ embryos with anoxic preconditioning

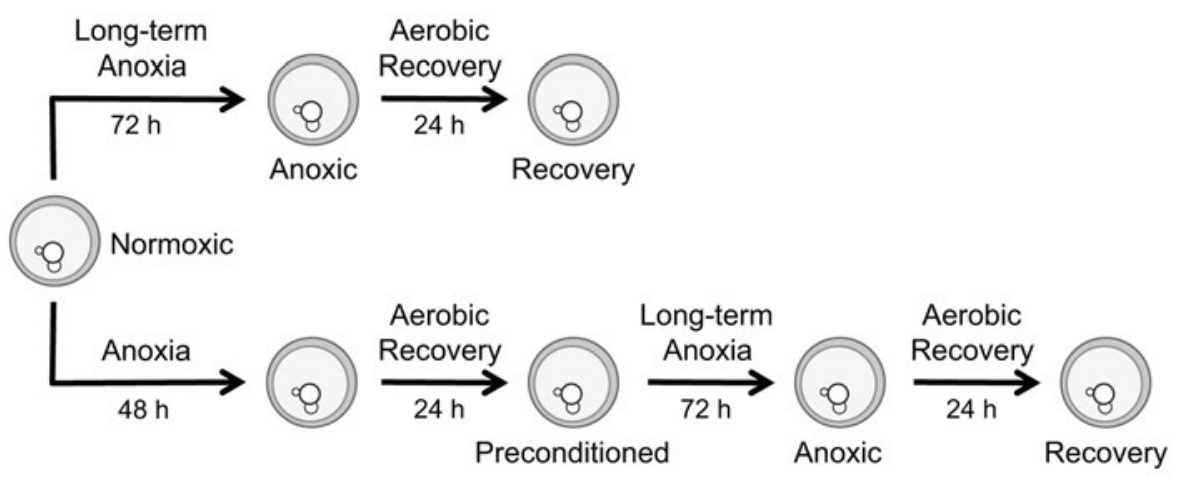

Fig 1.

Sampling regimen for embryos exposed to anoxia and subsequent recovery from anoxia for western blot analysis. 
A
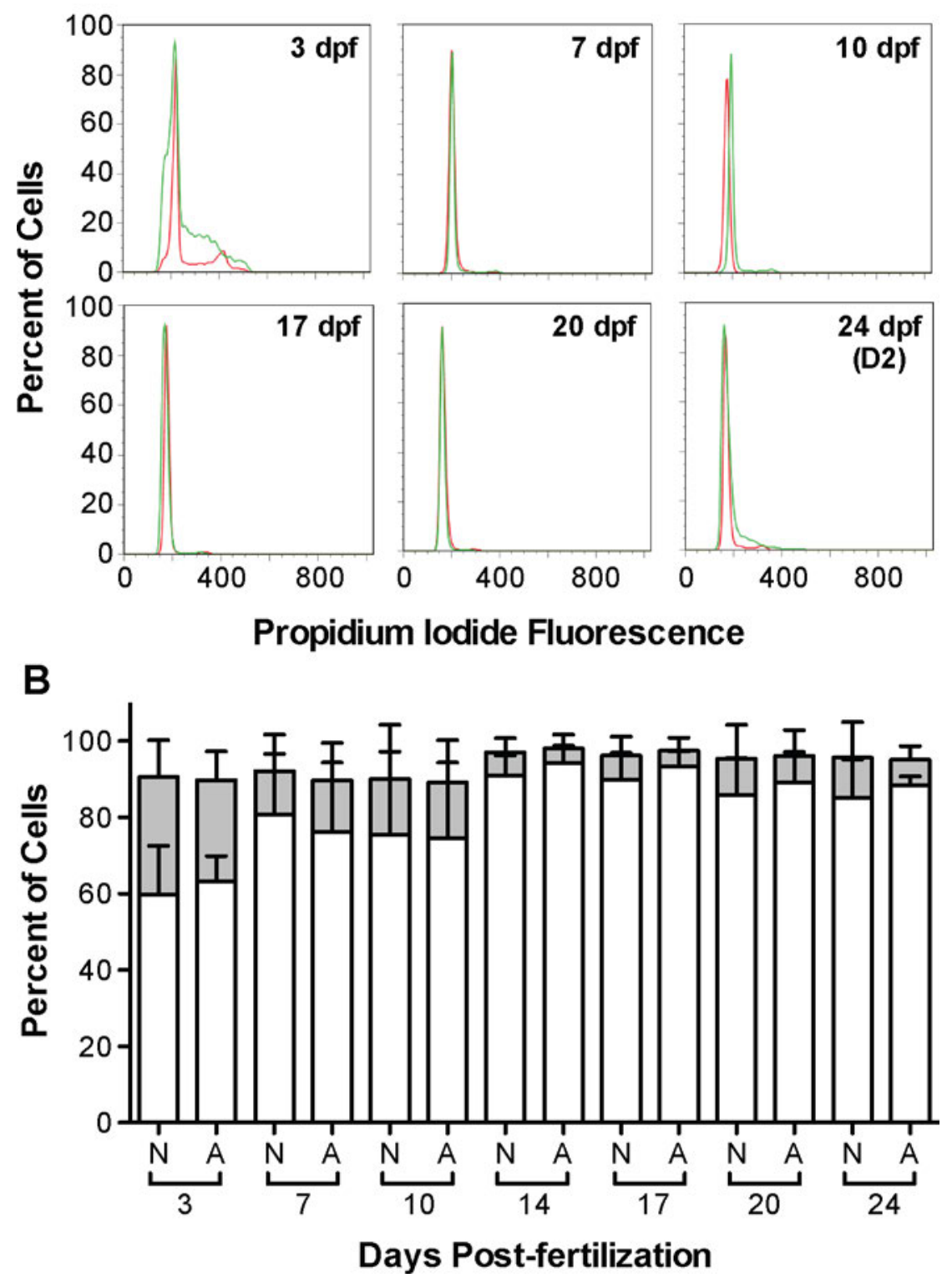

Fig 2.

Flow cytometry analysis of DNA content (A) in cells isolated from $A$. limnaeus embryos during early development through diapause II ( $24 \mathrm{dpf}$ ) that were exposed to normoxia (green) or 24h of anoxia (red). Most cells have a diploid amount of DNA and thus are in the $\mathrm{G}_{1} / \mathrm{G}_{0}$ phase of the cell cycle during early development through diapause II. (B) There is an increase in the proportion of cells that are observed in $\mathrm{G}_{1}$ (white) and a decrease in those in $\mathrm{G}_{2}$ (gray) as embryos complete early development and enter diapause II. Bars are means \pm range $(n=2)$. 
A

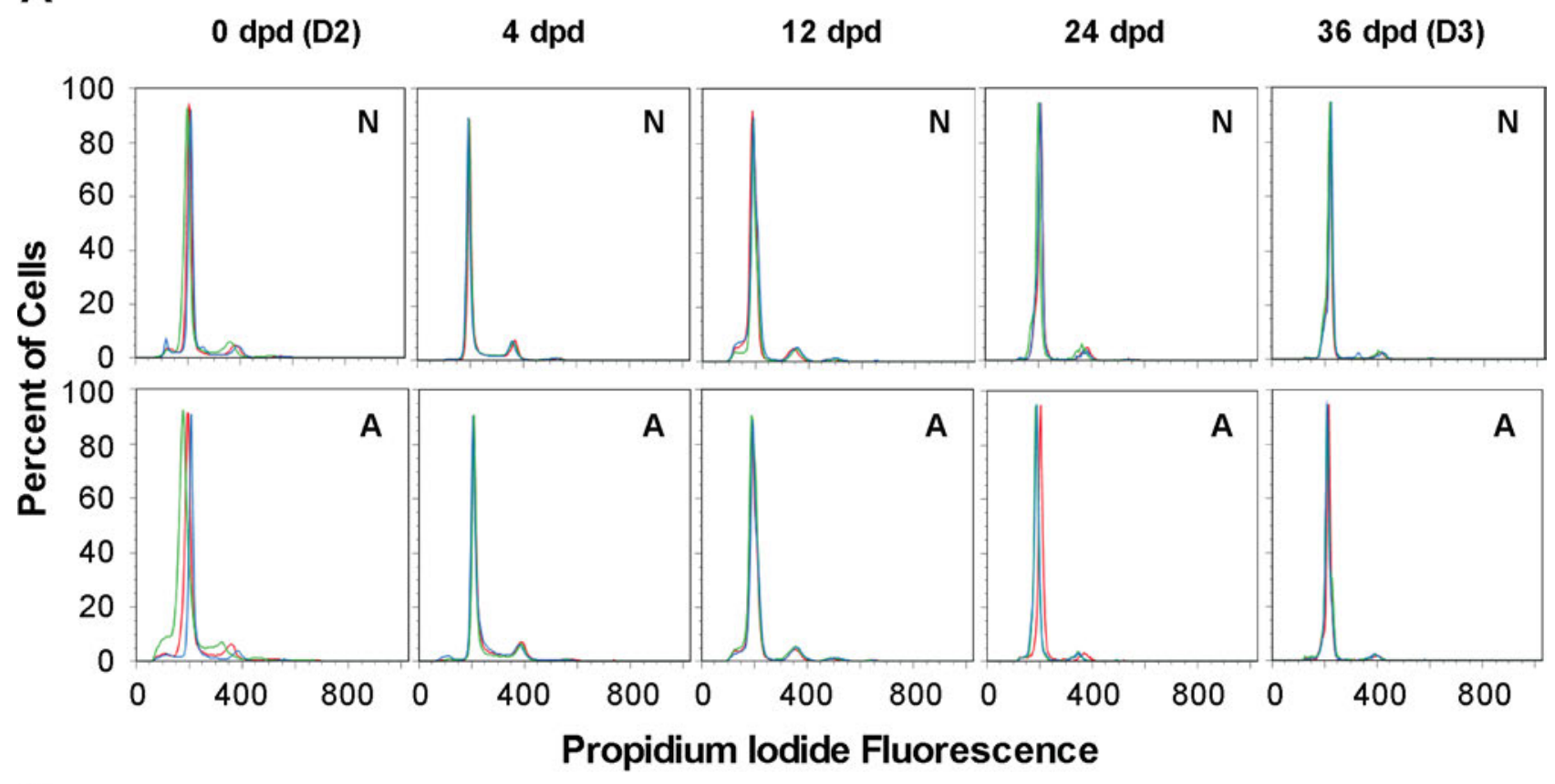

B

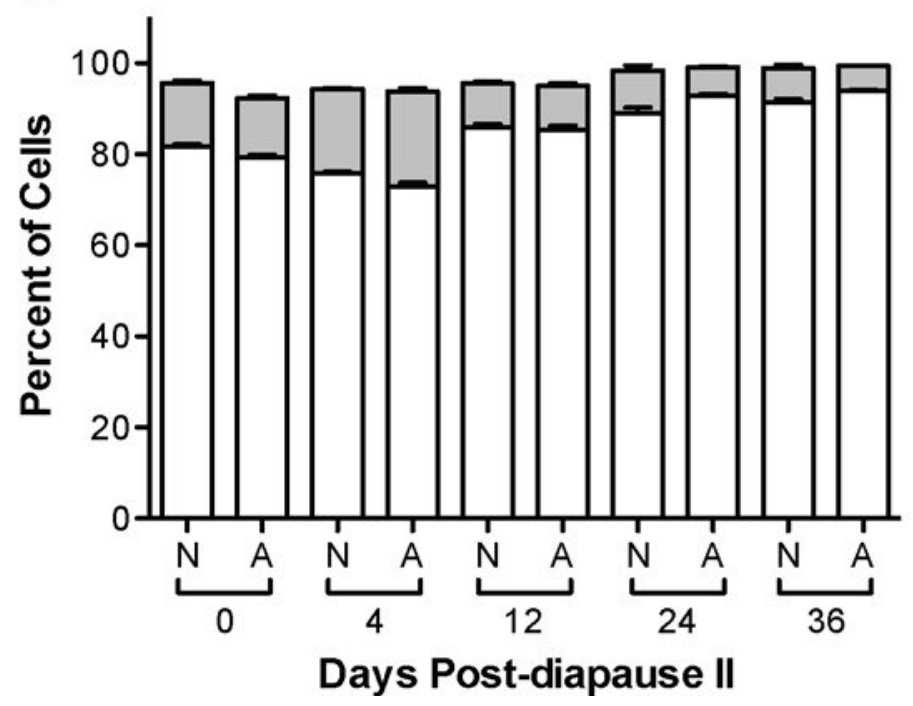

Fig 3.

Flow cytometry analysis of DNA content (A) in cells isolated from post-diapause II embryos exposed to normoxia (N) or $24 \mathrm{~h}$ of anoxia (A). The age of the embryos is listed above the panels. Three independent replicates $(n=3)$ are presented for each stage (green, red, blue). (B) The proportion of cells in $\mathrm{G}_{1}$ (white) and $\mathrm{G}_{2}$ (gray) is unaltered by exposure to anoxia (two-way ANOVA, $\mathrm{p}=0.15$ ), but is significantly different in the different post-diapause II embryos incubated aerobically (Two-way ANOVA, F(4,10)=148.7, $p<0.0001$ ). Bars are means \pm S.E.M. $(n=3)$. 


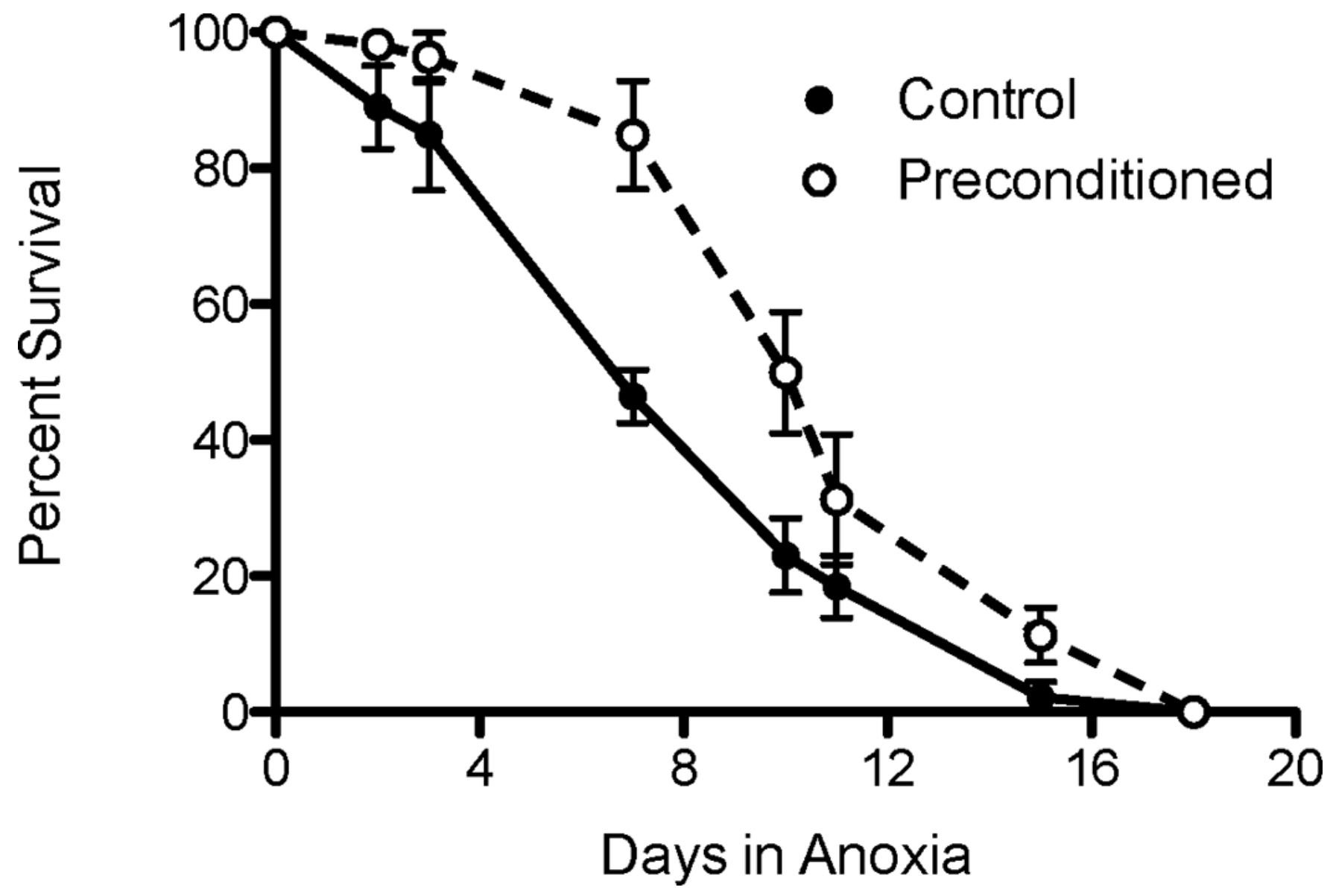

Fig 4.

Survival of 12 dpd embryos of $A$. limnaeus exposed to anoxic preconditioning ( $48 \mathrm{~h}$ anoxia $+24 \mathrm{~h}$ recovery) is significantly enhanced (two-way ANOVA, $F(7,56)=122.57, p<0.0001$;

Probit regression relative median potency analysis, $\mathrm{p}<0.05)$ in preconditioned $\left(\mathrm{LT}_{50}=\right.$ $10.2 \pm 0.8 \mathrm{~d})$ compared to control embryos $\left(\mathrm{LT}_{50}=7.4 \pm 0.7 \mathrm{~d}\right)$. Symbols represent means \pm S.E.M. $(n=5)$. 
$50 \mathrm{kDa}-$
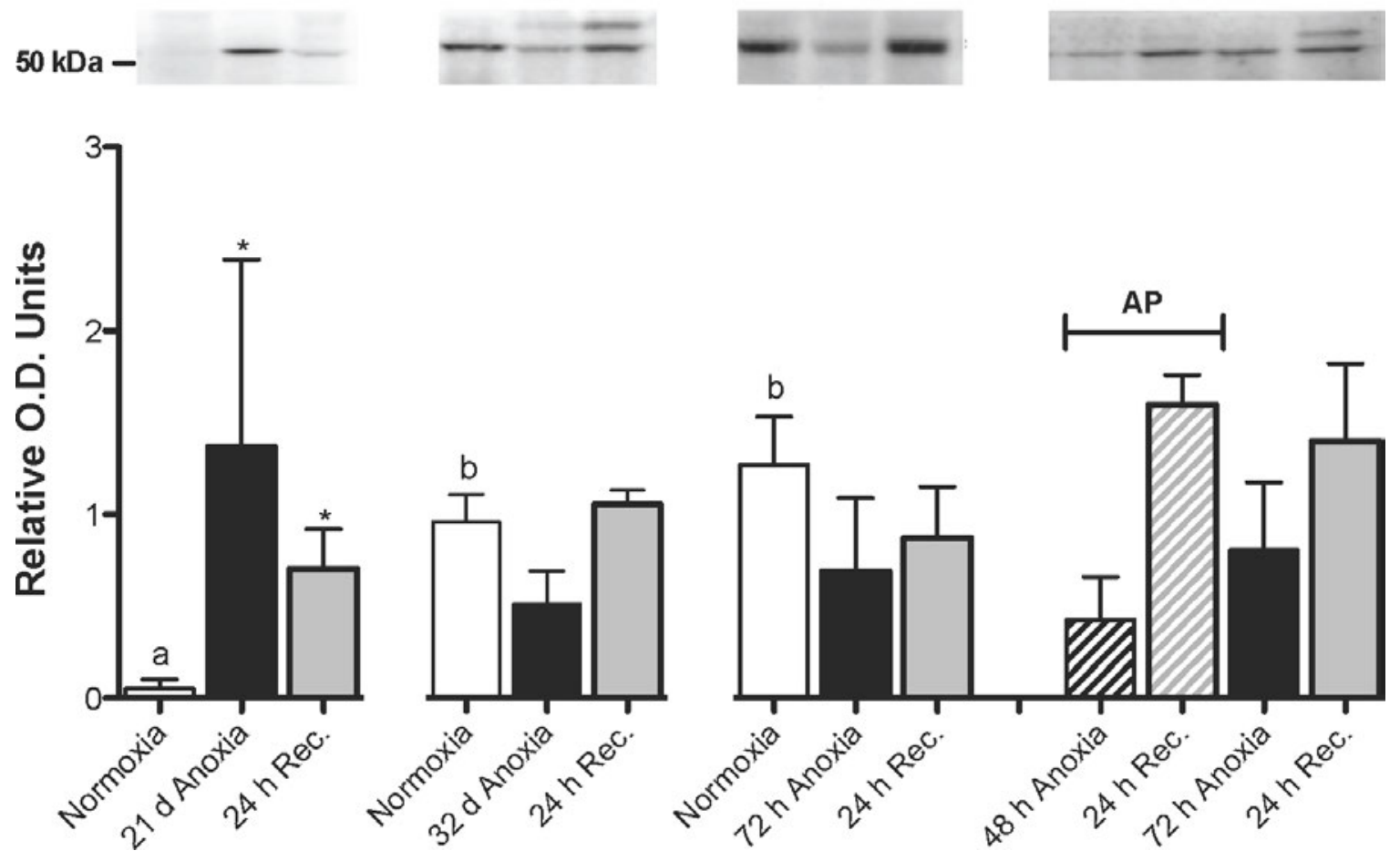

Fig 5.

Protein expression of p53 in diapause II, $4 \mathrm{dpd}$ and $12 \mathrm{dpd}$ embryos exposed to normoxia, anoxia, or anoxic preconditioning (AP) as described in Fig 1. Diapause II, 4 dpd, and 12 dpd embryos were exposed to aerobic incubation (Normoxia), anoxia equal to $0.5 * \mathrm{LT}_{50}(21 / 32 \mathrm{~d}$ or $72 \mathrm{~h}$ Anoxia), and $24 \mathrm{~h}$ of recovery from the anoxic exposure ( $24 \mathrm{~h} \mathrm{Rec}$.). Embryos at 12 $\mathrm{dpd}$ were also exposed to anoxic preconditioning (AP, $48 \mathrm{~h}$ anoxia $+24 \mathrm{~h}$ aerobic recovery) prior to exposure to anoxia for $0.5 * \mathrm{LT}_{50}(72 \mathrm{~h}$ Anoxia) and subsquent aerobic recovery for $24 \mathrm{~h}$ (24 h Rec.). Bars represent means \pm S.E.M. $(\mathrm{n}=3)$. A significant increase in p53 expression (asterisks) was observed in diapause II embryos exposed to anoxia (Dunnett's post hoc, $p<0.05$ ). Diapause II embryos have signficantly less p53 under normoxic conditions compared to either post-diapause II stage (bars with different letters are statisically different, Tukey's post hoc, $\mathrm{p}<0.05)$. Representative western blots are provided above the graph. 

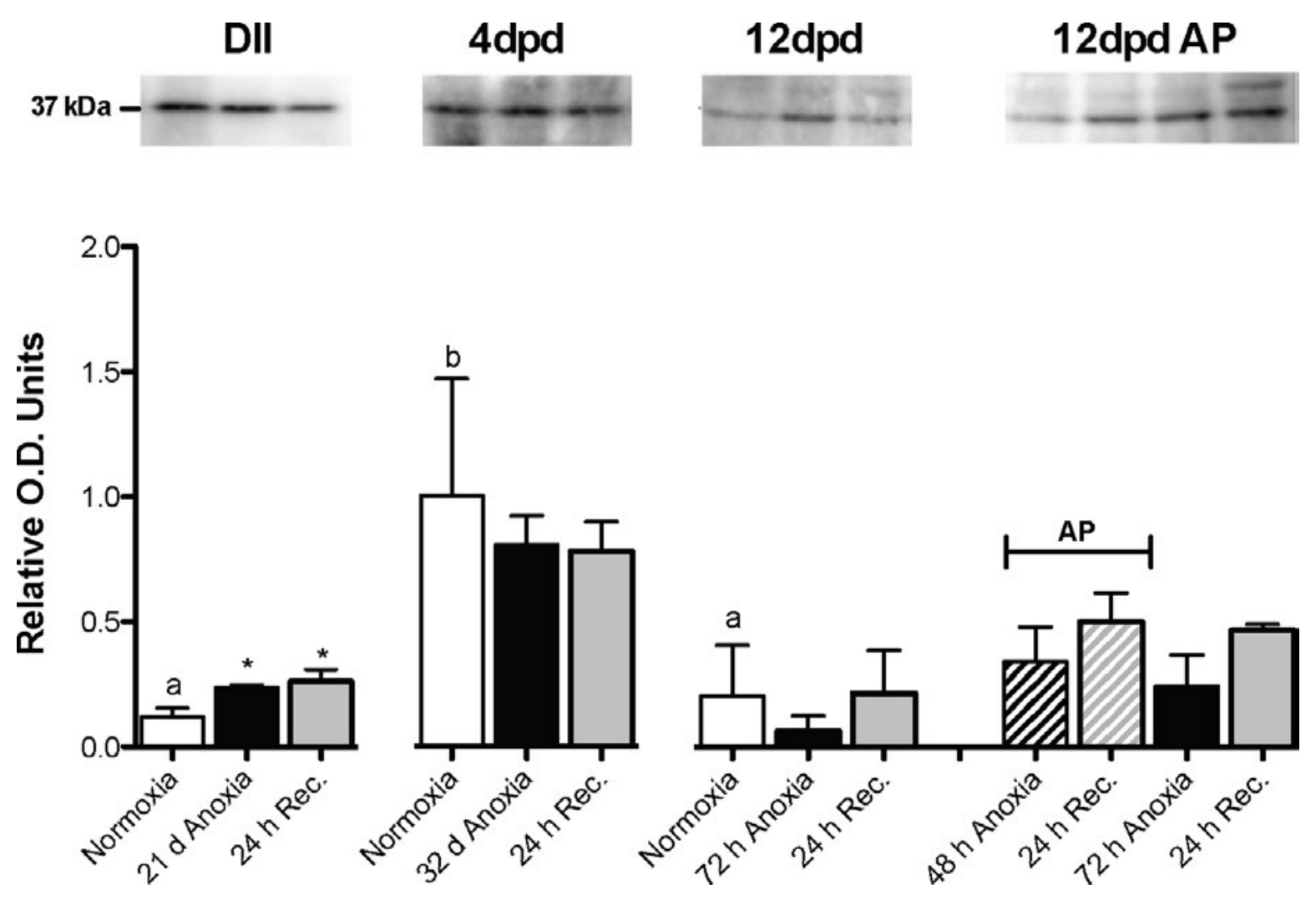

Fig 6.

Cyclin D1 expression in diapause II, $4 \mathrm{dpd}$ and $12 \mathrm{dpd}$ embryos exposed to normoxia, anoxia, or anoxic preconditioning (AP) as described in Figure 1. Diapause II, 4 dpd, and 12 dpd embryos were exposed to aerobic incubation (Normoxia), anoxia equal to $0.5 * \mathrm{LT}_{50}$ (21/32 d or $72 \mathrm{~h}$ Anoxia), and $24 \mathrm{~h}$ of recovery from the anoxic exposure ( $24 \mathrm{~h} \mathrm{Rec}$.). Embryos at $12 \mathrm{dpd}$ were also exposed to anoxic preconditioning (AP, $48 \mathrm{~h}$ anoxia $+24 \mathrm{~h}$ aerobic recovery) prior to exposure to anoxia for $0.5 * \mathrm{LT}_{50}(72 \mathrm{~h}$ Anoxia) and subsquent aerobic recovery for $24 \mathrm{~h}$ ( $24 \mathrm{~h}$ Rec.). Bars represent means \pm S.E.M. $(\mathrm{n}=3)$. Anoxia causes a statistically significant increase in cyclin D1 levels (asterisks) in diapause II embryos (Dunnett's post hoc, $p<0.05$ ). Normoxic 4 dpd embryos have significantly higher levels of cyclin D1 compared to embryos in diapause II and at $12 \mathrm{dpd}$ (bars with different letters are statistically different, Tukey's post hoc, $\mathrm{p}<0.05$ ). Representative western blots are provided above the graph. 


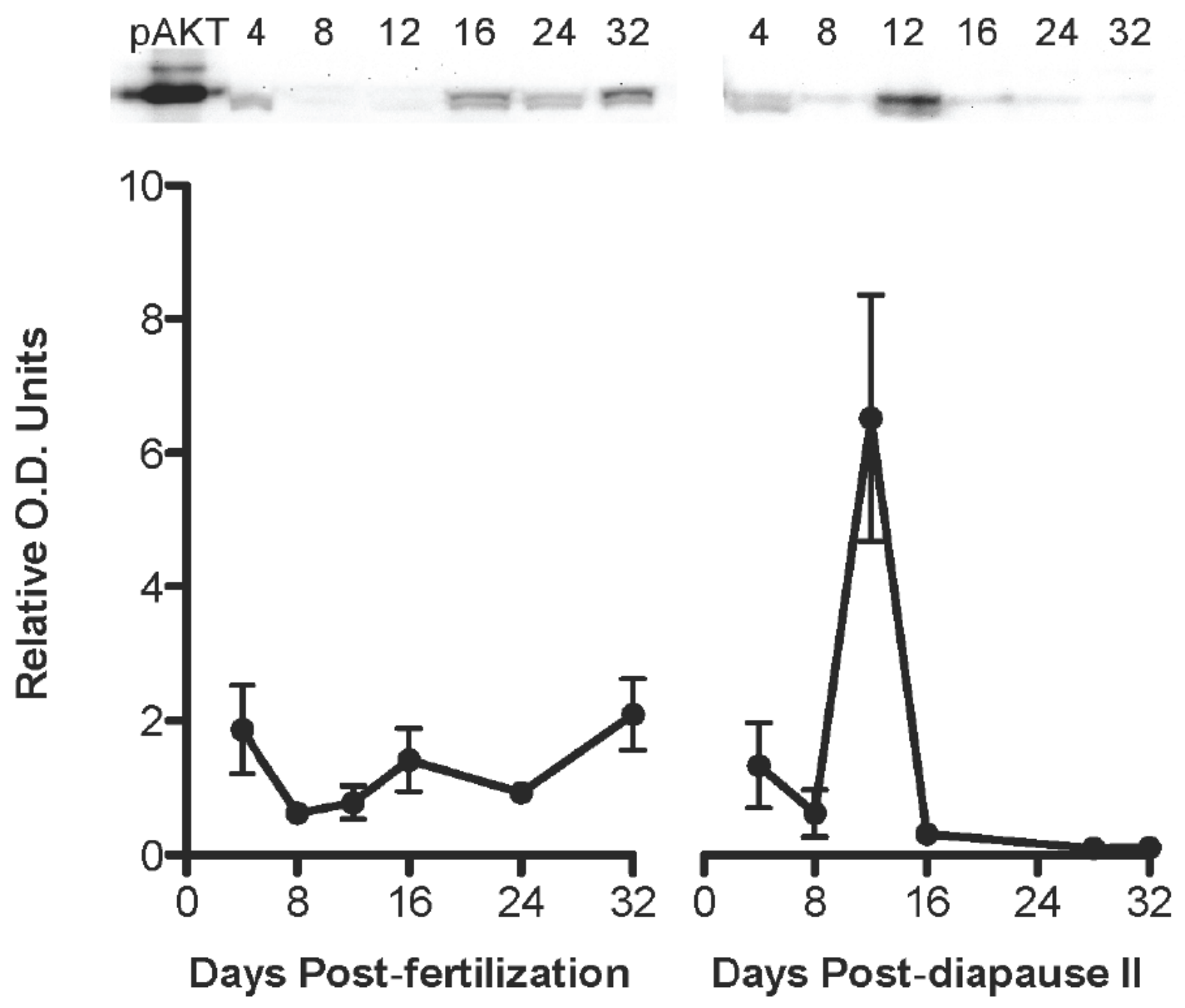

Fig 7.

pAKT protein levels in normoxic embryos of $A$. limnaeus during embryonic development. Aside from the large spike observed in embryos $12 \mathrm{dpd}$, levels of pAKT are high in diapause II embryos and fall during post-diapause II development. Symbols represent mean \pm S.E.M. $(n=4)$. Representative western blots are provided above the graph. 

0
1
48
$1 \mathrm{R}$
$6 \mathrm{R}$
$24 \mathrm{R}$

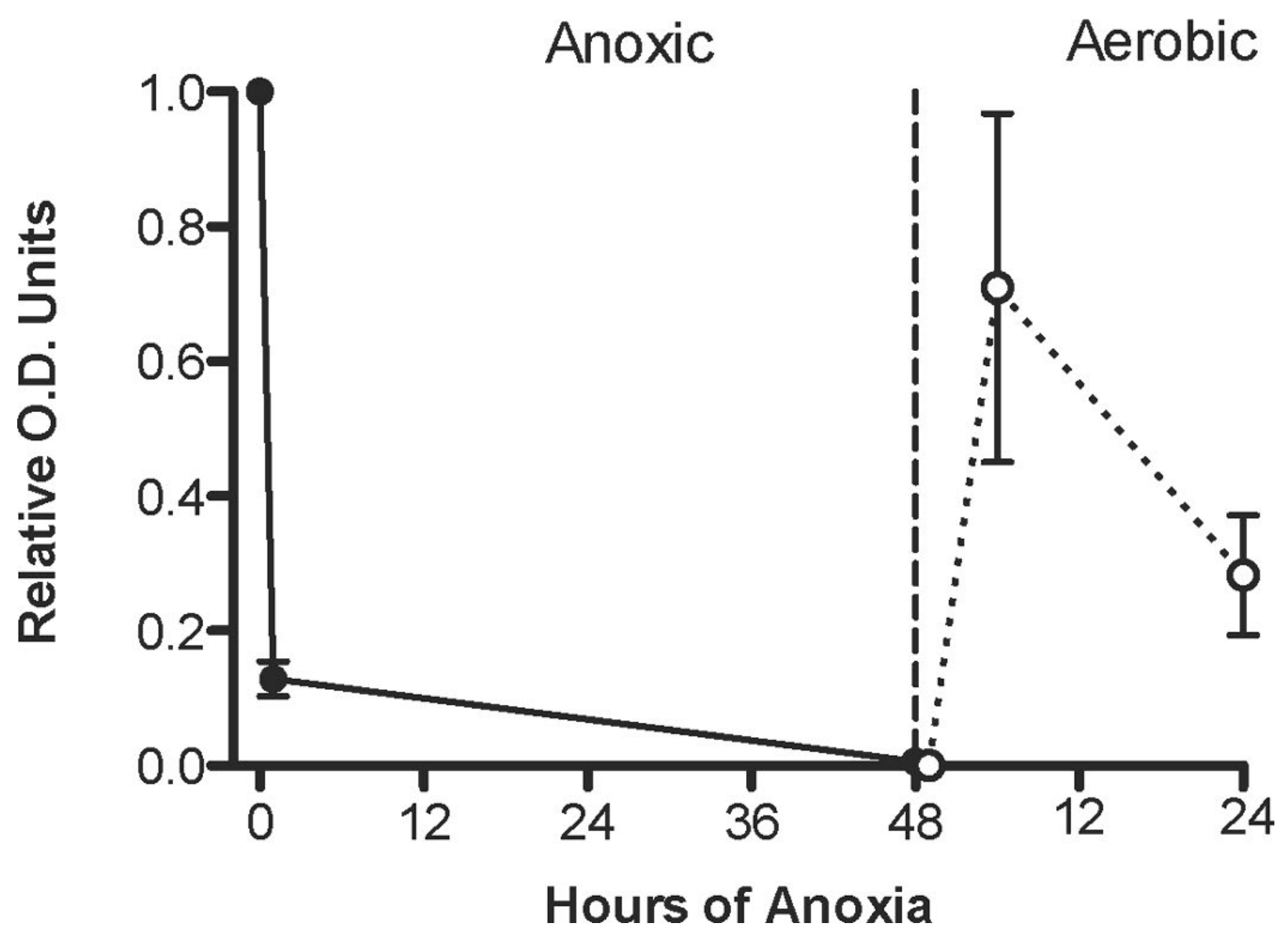

Fig 8.

Levels of pAKT plummet in $12 \mathrm{dpd}$ embryos of $A$. limnaeus exposed to $48 \mathrm{~h}$ of anoxia and do not return to control levels after $24 \mathrm{~h}$ of aerobic recovery. Symbols represent mean \pm S.E.M. $(\mathrm{n}=3) .1 \mathrm{R}=48 \mathrm{~h}$ or anoxia $+1 \mathrm{~h}$ of aerobic recovery, $6 \mathrm{R}=48 \mathrm{~h}$ of anoxia $+6 \mathrm{~h}$ of aerobic recovery, $24 \mathrm{R}=48 \mathrm{~h}$ of anoxia $+24 \mathrm{~h}$ of aerobic recovery. Representative western blots are provided above the graph. 


\section{Table 1}

Developmental stages of Austrofundulus limnaeus used in this study.

\begin{tabular}{|c|c|c|c|c|}
\hline $\operatorname{dpf}^{a}$ & $\operatorname{dpd}^{b}$ & $\mathrm{ws}^{c}$ & Description & $\mathbf{L T}_{\mathbf{5 0}}$ Anoxia, $\mathrm{d}^{d}$ \\
\hline 3 & & 19 & $100 \%$ epiboly, all deep blastomeres randomly distributed on yolk surface & 16 \\
\hline 7 & & $22-26$ & Dispersion/Reaggregation, all deep blastomeres distributed on yolk surface & 27 \\
\hline 10 & & 28 & Definitive embryonic axis, initiation of neurulation & \\
\hline 14 & & 30 & 10 pairs of somites, optic lobes present & 35 \\
\hline 17 & & $30-31$ & 15-20 pairs of somites, optic cups formed, beating tubular heart & 38 \\
\hline 20 & & 31 & 25 pairs of somites, optic cups and lens, RBC $e_{\text {reticulocytes, heart rate } 16-43 \mathrm{bpm}^{f}}$ & \\
\hline 24 & & 32 & $\begin{array}{l}\text { Early diapause II, } 42 \text { pairs of somites, optic cups and associated lens, otic vesicles, olfactory } \\
\text { placodes, heart rate } 4-10 \mathrm{bpm}\end{array}$ & 41 \\
\hline \multirow[t]{5}{*}{32} & 0 & 32 & Diapause II, same morphology as $24 \mathrm{dpf}$, but reduced metabolic rate, heart rate $0-10 \mathrm{bpm}$ & 62 \\
\hline & 4 & 36 & $\begin{array}{l}\text { Early organogenesis, simple linear gut tube, } \mathrm{Hb}^{g} \text { expressed in } \mathrm{RBCs} \text {, minor looping in heart } \\
\text { chambers apparent, heart rate } 60-100 \mathrm{bpm} \text {, faint eye pigmentation, melanocytes present on } \\
\text { anterior of embryo }\end{array}$ & $62-74$ \\
\hline & 12 & 40 & $\begin{array}{l}\text { Full overgrowth of embryo around yolk, looped gut tube, liver and gall bladder present, muscle } \\
\text { differentiation, caudal fin present, mouth opens, reflective material in eye, heart looping near } \\
\text { complete, heart rate } 80-106 \mathrm{bpm} \text {, }\end{array}$ & 7 \\
\hline & 24 & 43 & $\begin{array}{l}\text { Early diapause III, fully formed and ready to feed larvae, competent to hatch, heart rate } 30-100 \\
\text { bpm }\end{array}$ & 0.5 \\
\hline & 36 & 43 & Diapause III, same morphology as $24 \mathrm{dpd}$, but lower metabolic rate, heart rate $30-60 \mathrm{bpm}$ & 0.5 \\
\hline
\end{tabular}

${ }_{\mathrm{dpf}}=$ days post-fertilization

$b_{\text {dpd }}=$ days post-diapause II

$c_{\mathrm{WS}}=$ Wourms' Stage $($ Wourms, 1972c)

$d$ Approximate days to $50 \%$ mortality in anoxia at 25 C. Data from Podrabsky et al. $(2007,2012)$

$e_{\mathrm{RBC}}=$ red blood cell

$f_{\mathrm{bpm}}=$ beats $\min ^{-1}$

$g_{\mathrm{Hb}}=$ hemoglobin 